\title{
Alcohol consumption and risk of myelodysplastic syndromes: A meta-analysis of epidemiological studies
}

\author{
JIE JIN ${ }^{1,2^{*}}$, MENGXIA YU ${ }^{1,2^{*}}$, CHAO HU ${ }^{1,2^{*}}$, LI YE $^{1,2}$, LILI XIE $^{1,2}$, FEIFEI CHEN $^{1,2}$, \\ ZHENGPING ZHUANG ${ }^{3}$ and HONGYAN TONG ${ }^{1,2}$ \\ ${ }^{1}$ Department of Hematology, The First Affiliated Hospital of Zhejiang University, Hangzhou, Zhejiang 310003; \\ ${ }^{2}$ Institute of Hematology, Zhejiang University School of Medicine, Hangzhou, Zhejiang 310009, P.R. China; \\ ${ }^{3}$ Surgical Neurology Branch, National Institute of Neurological Disorders and Stroke, \\ National Institutes of Health, Bethesda, MD 20892, USA
}

Received June 18, 2014; Accepted July 22, 2014

DOI: $10.3892 / \mathrm{mco} .2014 .376$

\begin{abstract}
Previous studies on the association between alcohol intake and the risk of myelodysplastic syndromes (MDS) have been inconclusive. We conducted a meta-analysis to evaluate alcohol intake as a risk factor for MDS. We performed a systematic literature search of articles published before March, 2014 using Web of Science, PubMed and the Cochrane Library. Two evaluators independently selected and reviewed studies based on predetermined selection criteria. The fixed- or random-effects models were used to summarize the estimates of odds ratios (ORs) with $95 \%$ confidence intervals (CIs). A total of 9 studies (8 case-control and 1 cohort) met the inclusion criteria of this meta-analysis. No significant association was observed between alcohol consumption and MDS when comparing drinkers to non-drinkers $(\mathrm{OR}=1.16$, 95\% CI: $0.88-1.53$ ) or between subgroups stratified by alcohol history, gender, ethnicity, study design, source of patients or MDS subtypes. However, the data indicated a stronger association of alcohol with MDS in individuals who consumed $\geq 10 \mathrm{~g} /$ day $(\mathrm{OR}=1.55,95 \% \mathrm{CI}: 1.08-2.21)$ vs. those who consumed $<10 \mathrm{~g} /$ day $(\mathrm{OR}=1.09,95 \% \mathrm{CI}$ : $0.78-1.53)$. This meta-analysis suggests that alcohol intake may increase the risk of MDS in a dose-dependent manner. However, additional well-designed, prospective cohort studies are required to verify these findings and identify other risk factors associated with MDS.
\end{abstract}

Correspondence to: Professor Hongyan Tong, Department of Hematology, The First Affiliated Hospital of Zhejiang University, 79 Qingchun Road, Hangzhou, Zhejiang 310003, P.R. China E-mail: zjuhongyantong@163.com

${ }^{*}$ Contributed equally

Key words: alcohol drinking, myelodysplastic syndromes, meta-analysis, epidemiological studies

\section{Introduction}

Myelodysplastic syndromes (MDS) are disorders characterized by ineffective bone marrow hematopoiesis, clonal proliferation of hematopoietic stem cells and increased apoptosis (1), resulting in peripheral cytopenias. The incidence of MDS increases with age and it is most prevalent in male Caucasians. A recent study using the SEER-Medicare database revealed that the incidence of MDS was as high as 75 per 100,000 individuals aged $\geq 65$ years; however, the incidence was $<5$ per 100,000 individuals aged $\leq 50$ years (2). With the growth of the aging population worldwide, the MDS burden of disease is expected to escalate in the near future. To date, the most definitive risk factors for MDS are age, ethnicity and smoking $(3,4)$. However, clear differences between ethnic and geographical populations have yet to be defined. Hence, further investigation of additional risk and protective factors is required to improve prevention and early diagnosis of MDS.

Alcohol consumption is commonly practiced worldwide. Alcohol is associated with certain diseases and is estimated to account for $3.2 \%$ of all cancer cases and $5 \%$ of cancer-related deaths worldwide (5-7). In epidemiological studies, including cohort and case-control studies, the possible association between alcohol intake and the risk of MDS has been investigated, but the findings are inconclusive. Two case-control studies reported a positive correlation between alcohol intake and MDS $(8,9)$, whereas 6 case-control studies reported a non-significant association between the two (10-15). By contrast, one prospective cohort study suggested that alcohol consumption may decrease the risk of MDS (16). These conflicting reports are reflective of the complex effects of alcohol consumption on the human body, as well as the heterogeneity of the parameters used among the different studies. We performed a meta-analysis of all relevant published literature in order to better define the association between alcohol consumption and MDS.

\section{Materials and methods}

Literature research. A systematic literature search was conducted by two independent reviewers (Chao $\mathrm{Hu}$ and 
Mengxia Yu) using PubMed, the Cochrane Library and Web of Science. The following search specifications were used: alcohol, or ethanol, or drinking behavior, or alcoholic beverages, or wine, or beer or liquor, or spirit and myelodysplastic syndrome, or MDS, or myelodysplastic, or myelodysplasia, or preleukemia. The titles and abstracts of the relevant articles were selected and full-text articles were retrieved. We also reviewed the reference lists from original articles for additional studies not identified in the database search.

Study selection. The studies included in this meta-analysis were required to meet all the following criteria: i) cohort or case-control studies; ii) the exposure of interest was alcohol intake; iii) the outcome of interest was MDS; iv) risk and corresponding 95\% confidence intervals (CIs) were reported or could be calculated from the data; and v) the identified studies were written in the English language. If there were multiple publications from the same study or overlapping study populations, only the study with the largest number of cases was included in the meta-analysis.

Data extraction. The following data were extracted from each study and included in the final analysis: first author's name, year of publication, country of origin, gender, age, study design, source of patients, number of cases/controls, risk factor assessment, matching and adjusted covariates. We contacted the corresponding authors of the primary studies for missing information when necessary. As MDS is a rare disease, the relative risk in prospective cohort studies is approximately equivalent to the odds ratio (OR) (17). This allows data from cohort and case-control studies to be combined and OR to be used as a measure of outcome (18). Data extraction was performed independently by two reviewers using a predefined data collection form. To resolve any discrepancies, a third reviewer also extracted the data and the results were attained by consensus. The quality of each study was appraised independently by two reviewers who used the nine-score Newcastle-Ottawa Scale (19).

Statistical analysis. A fixed-effects model with the method of Mantel-Haenszel was used to calculate a pooled OR with 95\% CI when there was no heterogeneity (20). Otherwise, the random-effects model with the method of DerSimonian and Laird (21) was used for pooling ORs. Heterogeneity was assessed by using the $\mathrm{Q}$ statistic and the $\mathrm{I}^{2}$ score. $\mathrm{P}>0.05$ for the Q-test was considered as a lack of heterogeneity among the studies. While publication bias was not expected, we assessed this possibility using Begg's funnel plots (rank correlation method, where an asymmetrical plot indicated a possible publication bias) (22) and Egger's bias test (linear regression method, where $\mathrm{P}<0.05$ suggested the presence of statistically significant publication bias) (23). A sensitivity analysis was conducted by sequential omission of studies under various contrasts to reflect the effect of individual data on the pooled ORs and evaluate the stability of the results. Stratified analyses were performed by alcohol history, gender, ethnicity, study design, sample source, disease subtype and quantity of alcohol per day. All the statistical analyses were conducted with STATA 11.0 software (StataCorp, College Station, TX, USA) using two-tailed $\mathrm{P}$-values. $\mathrm{P}<0.05$ was considered to indicate a statistically significant difference.

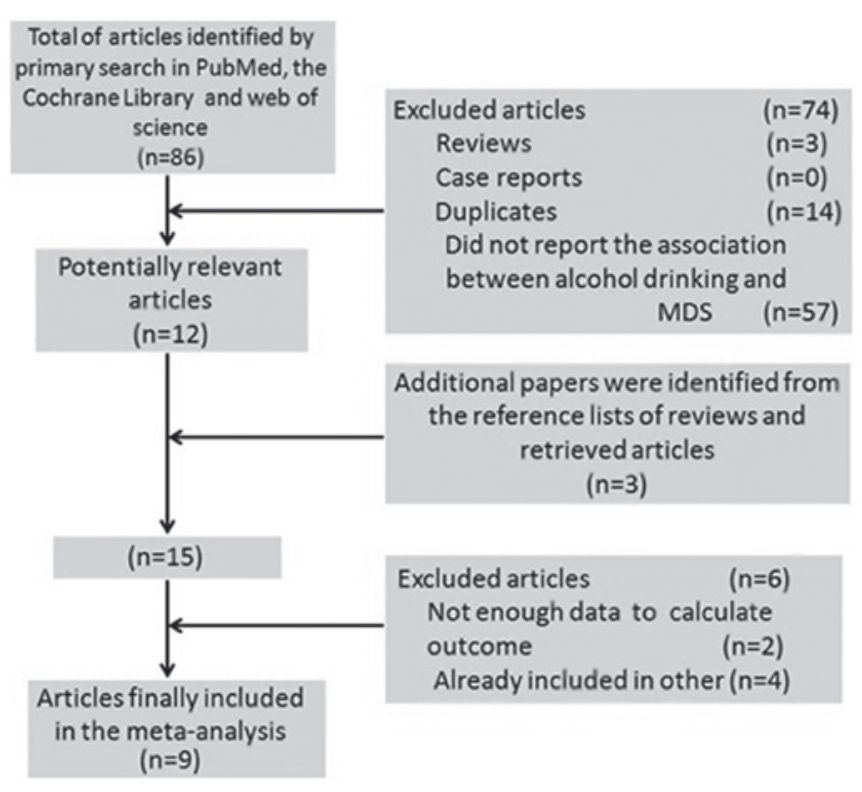

Figure 1. Flow diagram of study selection. MDS, myelodysplastic syndrome.

\section{Results}

Literature search and study characteristics. The detailed steps of our literature search are illustrated in Fig. 1. A total of 9 studies were selected for the present meta-analysis, including 1 prospective cohort (16) and 8 case-control studies (8-15) published between 1991 and 2011. These studies were conducted in the following regions: United States $(n=4)$, Europe $(n=2)$ and Asia $(n=3)$. A total of 1,448 MDS patients were included in this meta-analysis. Information regarding alcohol intake was collected by interviews, self-administered questionnaires, or both. The study quality scores, evaluated by the Newcastle-Ottawa Quality Assessment Scale, ranged between 6 and 8 (with a mean of 6.7). The general characteristics of the 9 studies are summarized in Table I.

Risk assessment. There was no significant association between alcohol consumption and MDS when comparing individuals with any history of alcohol consumption to non-drinkers (OR=1.16, 95\% CI: 0.88-1.53) (Fig. 2). A statistically significant heterogeneity was found among the 9 studies $(\mathrm{P}=0.001)$ and, thus, a random-effects analysis was performed $\left(\mathrm{I}^{2}=70.0 \%\right)$.

For the sensitivity analysis, the effect of any single study on the overall estimate was assessed by repeating the meta-analysis while omitting one study at a time. The results indicated that no study considerably affected the summary of the risk estimate. The 9 study-specific ORs ranged from 0.98 (95\% CI: $0.85-1.14)$ to 1.25 (95\% CI: 0.93-1.68) when the studies by Pekmezovic et al (8) and by Ma et al (16) were omitted, respectively (Fig. 3).

Begg's and Egger's tests were used to assess the publication bias (Fig. 4). No publication bias was identified by either test $(\mathrm{P}=0.251$ and $\mathrm{P}=0.170$, respectively).

Subgroup analyses. Stratified group analyses were performed for the following subgroups: drinking status (current or former drinkers), gender, ethnicity (Asian or Caucasian), study design (case-control or cohort), patient source (population- 
Table I. Main characteristics of cohort and case-control studies evaluating the association between alcohol drinking and MDS.

\begin{tabular}{|c|c|c|c|c|c|c|c|c|c|c|c|}
\hline $\begin{array}{l}\text { Study } \\
\text { (year) }\end{array}$ & Country & Gender & $\begin{array}{c}\text { Age } \\
\text { (years) }\end{array}$ & $\begin{array}{l}\text { Study } \\
\text { design }\end{array}$ & Source & $\begin{array}{l}\text { No. of } \\
\text { cases }\end{array}$ & $\begin{array}{l}\text { No. of } \\
\text { controls }\end{array}$ & $\begin{array}{l}\text { Risk factor } \\
\text { assessment }\end{array}$ & $\begin{array}{l}\text { Study } \\
\text { quality }\end{array}$ & $\begin{array}{l}\text { Matching and } \\
\text { adjustments }\end{array}$ & (Refs.) \\
\hline
\end{tabular}

\begin{tabular}{|c|c|c|c|c|c|c|c|c|c|c|}
\hline $\begin{array}{l}\text { Lv et al } \\
(2011)\end{array}$ & China & $\mathrm{M} / \mathrm{F}$ & $20-88$ & $\begin{array}{l}\text { Case- } \\
\text { control }\end{array}$ & $\mathrm{HB}$ & 403 & 806 & $\begin{array}{l}\text { Face-to-face } \\
\text { interview }\end{array}$ & 6 & $\begin{array}{l}\text { Age, gender, anti-TB } \\
\text { drugs, D860, TCM, }\end{array}$ \\
\hline
\end{tabular}
alcohol intake, benzene, pesticides, gasoline, glues, hair dye, education, new building

\begin{tabular}{|c|c|c|c|c|c|c|c|c|c|c|c|}
\hline $\begin{array}{l}\text { Ma et al } \\
(2009)\end{array}$ & $\begin{array}{l}\text { United } \\
\text { States }\end{array}$ & $\mathrm{M} / \mathrm{F}$ & $50-78$ & Cohort & PB & 193 & 471,799 & $\begin{array}{l}\text { Mailed } \\
\text { questionnaire }\end{array}$ & 8 & $\begin{array}{l}\text { Age, gender, race, } \\
\text { education, total energy } \\
\text { intake }\end{array}$ & (16) \\
\hline $\begin{array}{l}\text { Pekmezovic } \\
\text { et al (2006) }\end{array}$ & $\begin{array}{l}\text { Serbia } \\
\text { Monte- } \\
\text { negro }\end{array}$ & $\mathrm{M} / \mathrm{F}$ & $18-85$ & $\begin{array}{l}\text { Case- } \\
\text { control }\end{array}$ & $\mathrm{HB}$ & 80 & 160 & Interview & 6 & Age, gender & (8) \\
\hline $\begin{array}{l}\text { Strom et al } \\
(2005)\end{array}$ & $\begin{array}{l}\text { United } \\
\text { States }\end{array}$ & $\mathrm{M} / \mathrm{F}$ & $24-89$ & $\begin{array}{l}\text { Case- } \\
\text { control }\end{array}$ & $\mathrm{HB}$ & 352 & 443 & $\begin{array}{l}\text { Mailed } \\
\text { questionnaire }\end{array}$ & 7 & $\begin{array}{l}\text { Age, gender, ethnicity, } \\
\text { education, family history } \\
\text { of hematopoietic cancer, } \\
\text { alcohol intake, fertilizer, } \\
\text { herbicide, pesticide, } \\
\text { benzene, solvent, gasoline }\end{array}$ & (11) \\
\hline $\begin{array}{l}\text { Dalamaga } \\
\text { et al (2002) }\end{array}$ & Greece & $\mathrm{M} / \mathrm{F}$ & $44-86$ & $\begin{array}{l}\text { Case- } \\
\text { control }\end{array}$ & $\mathrm{HB}$ & 84 & 84 & Interview & 6 & $\begin{array}{l}\text { Age, gender, marital } \\
\text { status, education, } \\
\text { alcohol consumption, } \\
\text { time since first diagnosis } \\
\text { of an autoimmune } \\
\text { disorder }\end{array}$ & (12) \\
\hline $\begin{array}{l}\text { Nagata et al } \\
\text { (1999) }\end{array}$ & Japan & $\mathrm{M} / \mathrm{F}$ & $20-74$ & $\begin{array}{l}\text { Case- } \\
\text { control }\end{array}$ & $\mathrm{PB}$ & 111 & 815 & $\begin{array}{l}\text { Telephone } \\
\text { interview } \\
\text { and mailed } \\
\text { questionnaire }\end{array}$ & 8 & Age, gender, living area & (13) \\
\hline $\begin{array}{l}\text { Ido et al } \\
\text { (1996) }\end{array}$ & Japan & $\mathrm{M} / \mathrm{F}$ & $20-75$ & $\begin{array}{l}\text { Case- } \\
\text { control }\end{array}$ & $\mathrm{HB}$ & 116 & 116 & Interview & 6 & $\begin{array}{l}\text { Age, gender, hospital, } \\
\text { hair dye use, } \\
\text { occupational exposure } \\
\text { to organic solvents }\end{array}$ & (9) \\
\hline $\begin{array}{l}\text { Brown et al } \\
\text { (1992) }\end{array}$ & $\begin{array}{l}\text { United } \\
\text { States }\end{array}$ & M & $\leq 70$ & $\begin{array}{l}\text { Case- } \\
\text { control }\end{array}$ & $\mathrm{PB}$ & 100 & 820 & $\begin{array}{l}\text { Interview } \\
\text { and mailed } \\
\text { questionnaire }\end{array}$ & 7 & Age, state, tobacco & (14) \\
\hline $\begin{array}{l}\text { Crane and } \\
\text { Keating } \\
(1991)\end{array}$ & $\begin{array}{l}\text { United } \\
\text { States }\end{array}$ & NR & $\geq 18$ & $\begin{array}{l}\text { Case- } \\
\text { control }\end{array}$ & $\mathrm{HB}$ & 46 & 224 & $\begin{array}{l}\text { Telephone } \\
\text { interview } \\
\text { and mailed } \\
\text { questionnaire }\end{array}$ & 6 & $\begin{array}{l}\text { Age, gender, alcohol } \\
\text { intake, benzene, metal } \\
\text { fume, dyes, glues, } \\
\text { lacquers, varnishes, } \\
\text { radiation, pesticides, } \\
\text { paints, spray paints }\end{array}$ & (15) \\
\hline
\end{tabular}

MDS, myelodysplastic syndrome; M, male; F, female; HB, hospital-based; PB, population-based; TB, tuberculosis; TCM, traditional Chinese medicine; NR, not reported.

or hospital-based) and disease subtypes [refractory anemia (RA)/RA with ringed sideroblasts or RA with excess blasts (RAEB)/RAEB in transformation]. The ORs are shown in Table II. There were no significant differences between the subgroups. However, when we analyzed the amount of alcohol ingested per day, we observed a statistically significant hazardous effect on MDS (OR=1.55, 95\% CI: 1.08-2.21) with mild heterogeneity $\left(\mathrm{I}^{2}=16.2 \%\right)$ when the consumed amount of alcohol was $\geq 10 \mathrm{~g} /$ day. There was no publication bias in the subgroup analyses with either the Begg's or Egger's test.

\section{Discussion}

MDS are myeloid neoplasms characterized by dysplasia in one or more cell lines, with a significant impact on quality of life and survival (24). The pathophysiology of MDS has 


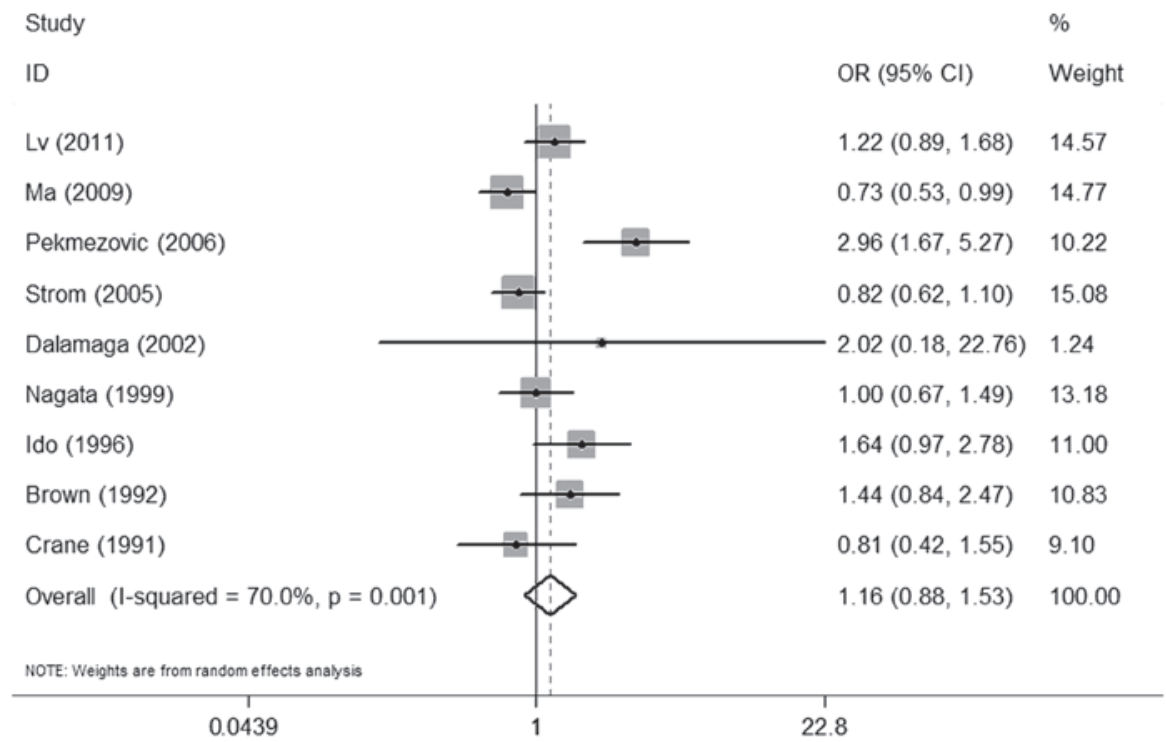

Figure 2. Forest plots depicting the risk estimates from included studies on the association between alcohol consumption and myelodysplastic syndrome. OR, odds ratio; CI, confidence interval.

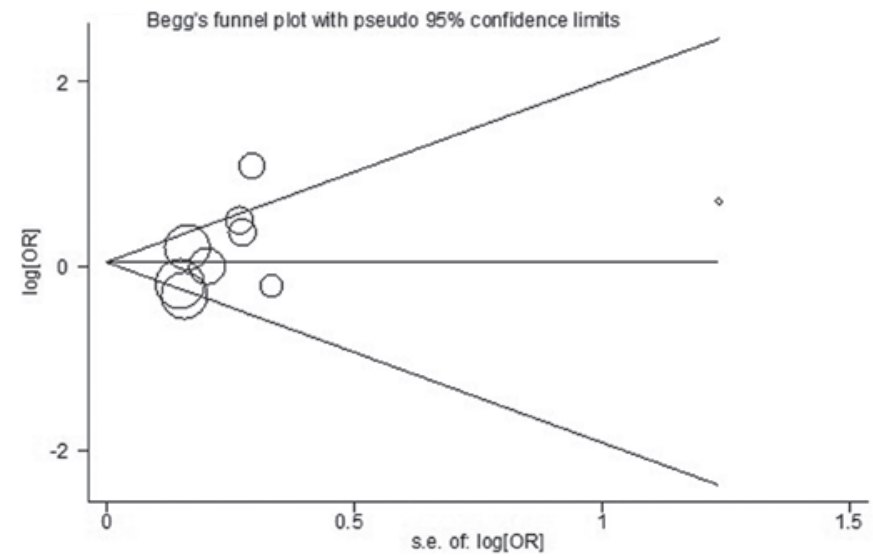

Figure 3. Begg's funnel plot of alcohol consumption and myelodysplastic syndrome, with pseudo $95 \%$ confidence limits. OR, odds ratio; SE, standard error.

not been fully elucidated. Alcohol consumption is a common practice worldwide and previous epidemiological studies have suggested that daily alcohol intake may be a risk factor for MDS; however, findings to date have been inconclusive. We attempted to clarify this potential association through a meta-analysis of 9 studies.

In this meta-analysis, there was a non-significant $16 \%$ risk of MDS with alcohol intake. Subgroup analyses also failed to demonstrate any significant correlations, except with an alcohol consumption of $\geq 10 \mathrm{~g} /$ day. Those individuals exhibited a $55 \%$ increased risk of MDS.

The effect of alcohol and its role in MDS is likely multifactorial. Our meta-analysis attests to the complicated nature of the mechanisms by which alcohol consumption may be involved the pathogenesis of MDS, which remain largely unknown at present. Several potential mechanisms have been proposed. First, alcohol may exert a direct toxic effect by causing bone marrow failure (25). Second, alcohol or one of its metabolites, such as methyl parathion, may induce chromosomal aberrations in hematopoietic cells (26). Third, hematological and immunological changes are known to be associated with alcohol. Alcohol was found to impair both the innate and acquired immune systems in heavy drinkers, thus increasing their susceptibility to infection (27). However, alcohol consumption may exert beneficial effects as well. In light-to-moderate drinkers, a recent study reported that alcohol may be beneficial for the immune system (27). At the molecular level, xanthohumol, a major prenylated flavonoid present in hops and beer, attracted considerable interest due to its latent cancer chemopreventive effect (28). In addition, resveratrol, an antioxidant found in the skin of grapes and abundant in red wine, has been shown to negatively affect initiation, promotion and progression of different types of cancer, including leukemia, in in vitro and in vivo studies $(29,30)$. Since MDS shares several characteristics with leukemia (31), resveratrol may also decrease the risk of MDS. Indeed, one recent study reported that wine drinkers had a $46 \%$ reduced risk of MDS (11). Hence, the effects of alcohol consumption may be dependent on the dose and type of alcoholic beverages. However, further studies are required to elucidate the underlying mechanisms.

The major strength of our meta-analysis is the number of large studies selected for review and analysis. This also allowed us to have enough data to perform multiple subgroup analyses. However, as with all meta-analyses of observational studies, our study had several limitations. First, the majority of the studies included in our meta-analysis were case-control studies, which depended on retrospective data, thus introducing the possibility of recall bias. Furthermore, combining data from different study designs may also be a source of bias. Second, the inclusion of articles only published in the English language may be a source of publication bias, despite the fact that by Begg's or Egger's tests, our results exhibited no evidence of publication bias. Third, there were three major types of alcoholic beverages (beer, wine, or spirits), which may exert different effects on MDS patients. However, the majority of the studies included in our analysis provided general data 
Table II. Stratified pooled odds ratios of the association between alcohol consumption and risk of MDS.

\begin{tabular}{|c|c|c|c|c|c|}
\hline Subgroup & $\begin{array}{l}\text { No. of studies } \\
\text { (refs.) }\end{array}$ & $\begin{array}{l}\text { Pooled OR } \\
(95 \% \mathrm{CI})\end{array}$ & $\begin{array}{l}\text { Q-test for heterogeneity } \\
\text { P-value }\left(\mathrm{I}^{2} \text { score, } \%\right)\end{array}$ & $\begin{array}{l}\text { Egger's test } \\
\text { P-value }\end{array}$ & $\begin{array}{l}\text { Begg's test } \\
\text { P-value }\end{array}$ \\
\hline \multicolumn{6}{|l|}{ Drinking status } \\
\hline Current & $2(10,13)$ & $1.05(0.73-1.52)$ & $0.151(51.4)$ & - & 1.000 \\
\hline Former & $2(10,13)$ & $1.21(0.80-1.83)$ & $0.684(0.0)$ & - & 1.000 \\
\hline \multicolumn{6}{|l|}{ Gender } \\
\hline Male & $4(9,11,13,14)$ & $1.07(0.83-1.38)$ & $0.059(56.0)$ & 0.347 & 0.806 \\
\hline Female & $3(9,11,13)$ & $0.78(0.52-1.18)$ & $0.368(0.0)$ & 0.612 & 1.000 \\
\hline \multicolumn{6}{|l|}{ Ethnicity } \\
\hline Asian & $3(9,10,13)$ & $1.31(0.85-1.51)$ & 0.149 (43.7) & 0.700 & 1.000 \\
\hline Caucasian & $6(8,11,12,14-16)$ & $0.91(0.65-1.28)$ & $<0.001(72.7)$ & 0.609 & 0.251 \\
\hline \multicolumn{6}{|l|}{ Study design } \\
\hline Cohort & $1(16)$ & $0.67(0.51-0.84)$ & - & - & - \\
\hline Case-control & $8(8-16)$ & $1.16(0.89-1.52)$ & $0.002(61.1)$ & 0.290 & 0.088 \\
\hline \multicolumn{6}{|l|}{ Source of patients } \\
\hline Population-based & $3(13,14,16)$ & $0.93(0.58-1.49)$ & $0.017(75.5)$ & 0.247 & 0.296 \\
\hline Hospital-based & $6(8-12,15)$ & $1.24(0.78-1.96)$ & $<0.001(75.6)$ & 0.351 & 0.368 \\
\hline \multicolumn{6}{|l|}{ MDS subtype } \\
\hline RA/RARS & $2(9,11)$ & $0.74(0.51-1.09)$ & $0.008(79.4)$ & - & 1.000 \\
\hline RAEB/RAEBt & $2(10,11)$ & $1.59(1.21-2.10)$ & $0.771(0)$ & - & 1.000 \\
\hline \multicolumn{6}{|c|}{ Quantity of drinking (g/day) } \\
\hline 0 & $4(9,10,13,14)$ & 1 & - & - & - \\
\hline$>0$ and $<10$ & $3(9,10,14)$ & $1.09(0.78-1.53)$ & $0.722(0.0)$ & 0.176 & 1.000 \\
\hline$\geq 10$ & $4(9,10,13,14)$ & $1.55(1.08-2.21)$ & $0.311(16.2)$ & 0.163 & 0.089 \\
\hline
\end{tabular}

MDS, myelodysplastic syndrome; OR, odds ratio; CI, confidence interval; RA, refractory anemia; RARS, RA with ringed sideroblasts; RAEB, RA with excess blasts; RAEBt, RAEB in transformation.

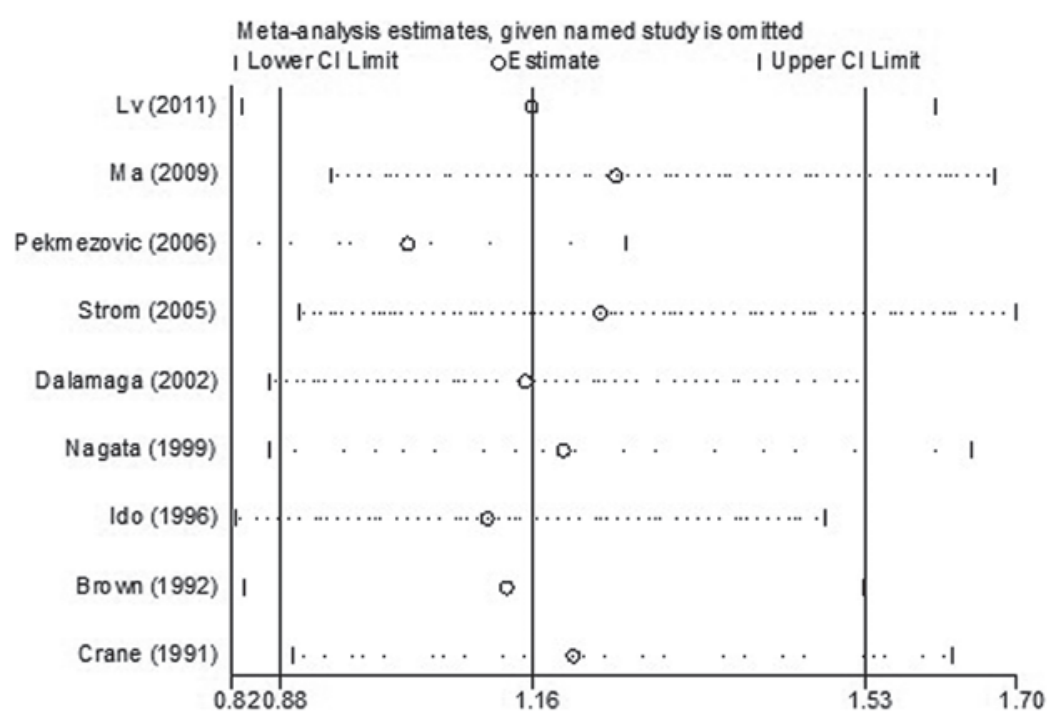

Figure 4. Sensitivity analysis by sequential omission of individual studies. CI, confidence interval.

on alcohol drinking rather than detailed information on the specific types of alcoholic beverages. Fourth, our meta-analysis was likely affected by the inaccuracy of self-reported alcohol consumption. Alcohol intake was recorded as number of glasses of beverage per day or week. However, glass size may vary considerably. Moreover, the accuracy of self-reported alcohol use has been known to be highly variable as well and one must consider telescopic or recall bias when evaluating this type of data.

In summary, our meta-analysis suggests that alcohol intake may increase the risk of developing MDS in a dose-dependent manner and heavy alcohol consumption is associated with a 
higher risk of MDS. Due to the limited number of studies, additional well-designed cohort or intervention studies are required to confirm these findings and help elucidate the pathophysiology of MDS.

\section{Acknowledgements}

This study was supported by grants from the Zhejiang Province Fund for Distinguished Young Scholars (no. LR12H08001), the Foundation of Key Innovation Team of Zhejiang Province (no. 2011R50015), the National Public Health Grand Research Foundation (no. 201202017), the Major Program of the Science Technology Department of Zhejiang Province Fund (no. 2013c03043-2) and the National Natural Science Foundation of China (nos. 30870914 and 81270582)

\section{References}

1. Raza A, Gezer S, Mundle S, et al: Apoptosis in bone marrow biopsy samples involving stromal and hematopoietic cells in 50 patients with myelodysplastic syndromes. Blood 86: 268-276, 1995.

2. Cogle CR, Craig BM, Rollison DE and List AF: Incidence of the myelodysplastic syndromes using a novel claims-based algorithm: high number of uncaptured cases by cancer registries. Blood 117: 7121-7125, 2011

3. Tong $\mathrm{H}, \mathrm{Hu} \mathrm{C}$, Yin X, Yu M, Yang J and Jin J: A meta-analysis of the relationship between cigarette smoking and incidence of myelodysplastic syndromes. PLoS One 8: e67537, 2013.

4. Ma X: Epidemiology of myelodysplastic syndromes. Am J Med 125 (Suppl 7): S2-S5, 2012.

5. Boffetta P and Hashibe M: Alcohol and cancer. Lancet Oncol 7: 149-156, 2006.

6. Danaei G, Vander Hoorn S, Lopez AD, Murray CJ and Ezzati M; Comparative Risk Assessment collaborating group (Cancers) Causes of cancer in the world: comparative risk assessment of nine behavioural and environmental risk factors. Lancet 366 : 1784-1793, 2005

7. de Menezes RF, Bergmann A and Thuler LC: Alcohol consumption and risk of cancer: a systematic literature review. Asian Pac J Cancer Prev 14: 4965-4972, 2013.

8. Pekmezovic T, Suvajdzic Vukovic N, Kisic D, et al: A case-control study of myelodysplastic syndromes in Belgrade (Serbia Montenegro). Ann Hematol 85: 514-519, 2006.

9. Ido M, Nagata C, Kawakami N, et al: A case-control study of myelodysplastic syndromes among Japanese men and women. Leuk Res 20: 727-731, 1996.

10. Lv L, Lin G, Gao X, et al: Case-control study of risk factors of myelodysplastic syndromes according to World Health Organization classification in a Chinese population. Am J Hematol 86: 163-169, 2011

11. Strom SS, Gu Y, Gruschkus SK, Pierce SA and Estey EH: Risk factors of myelodysplastic syndromes: a case-control study. Leukemia 19: 1912-1918, 2005.

12. Dalamaga M, Petridou E, Cook FE and Trichopoulos D: Risk factors for myelodysplastic syndromes: a case-control study in Greece. Cancer Causes Control 13: 603-608, 2002.
13. Nagata C, Shimizu H, Hirashima K, et al: Hair dye use and occupational exposure to organic solvents as risk factors for myelodysplastic syndrome. Leuk Res 23: 57-62, 1999.

14. Brown LM, Gibson R, Burmeister LF, Schuman LM, Everett GD and Blair A: Alcohol consumption and risk of leukemia, non-Hodgkin's lymphoma, and multiple myeloma. Leuk Res 16: 979-984, 1992.

15. Crane MM and Keating MJ: Exposure histories in acute nonlymphocytic leukemia patients with a prior preleukemic condition. Cancer 67: 2211-2214, 1991.

16. Ma X, Lim U, Park Y, et al: Obesity, lifestyle factors, and risk of myelodysplastic syndromes in a large US cohort. Am J Epidemiol 169: 1492-1499, 2009.

17. Zhang J and Yu KF: What's the relative risk? A method of correcting the odds ratio in cohort studies of common outcomes. JAMA 280: 1690-1691, 1998.

18. Hu ZH, Lin YW, Xu X, et al: No association between tea consumption and risk of renal cell carcinoma: a meta-analysis of epidemiological studies. Asian Pac J Cancer Prev 14: 1691-1695, 2013.

19. Wells GA, Shea B, O'Connell D, et al: The Newcastle-Ottawa Scale (NOS) for assessing the quality of nonrandomized studies in meta-analyses. http://www.ohri.ca/programs/clinical_epidemiology/oxford.asp. Accessed October, 19, 2009.

20. Mantel $\mathrm{N}$ and Haenszel W: Statistical aspects of the analysis of data from retrospective studies of disease. J Natl Cancer Inst 22: 719-748, 1959.

21. DerSimonian R and Laird N: Meta-analysis in clinical trials. Control Clin Trials 7: 177-188, 1986.

22. Begg CB and Mazumdar M: Operating characteristics of a rank correlation test for publication bias. Biometrics 50: 1088-1101, 1994.

23. Egger M, Davey Smith G, Schneider M and Minder C: Bias in meta-analysis detected by a simple, graphical test. BMJ 315: 629-634, 1997.

24. Newman K, Maness-Harris L, El-Hemaidi I and Akhtari M: Revisiting use of growth factors in myelodysplastic syndromes. Asian Pac J Cancer Prev 13: 1081-1091, 2012.

25. Casagrande $\mathrm{G}$ and Michot F: Alcohol-induced bone marrow damage: status before and after a 4-week period of abstinence from alcohol with or without disulfiram. A randomized bone marrow study in alcohol-dependent individuals. Blut 59: 231-236, 1989.

26. Sunil Kumar KB, Ankathil R and Devi KS: Chromosomal aberrations induced by methyl parathion in human peripheral lymphocytes of alcoholics and smokers. Hum Exp Toxicol 12: 285-288, 1993.

27. Diaz LE, Montero A, Gonzalez-Gross M, Vallejo AI, Romeo J and Marcos A: Influence of alcohol consumption on immunological status: a review. Eur J Clin Nutr 56 (Suppl 3): S50-S53, 2002.

28. Gerhauser C: Beer constituents as potential cancer chemopreventive agents. Eur J Cancer 41: 1941-1954, 2005.

29. Tsan MF, White JE, Maheshwari JG and Chikkappa G: Antileukemia effect of resveratrol. Leuk Lymphoma 43: 983-987, 2002.

30. Surh YJ, Hurh YJ, Kang JY, Lee E, Kong G and Lee SJ: Resveratrol, an antioxidant present in red wine, induces apoptosis in human promyelocytic leukemia (HL-60) cells. Cancer Lett 140: 1-10, 1999.

31. Steensma DP: Are myelodysplastic syndromes 'cancer'? Unexpected adverse consequences of linguistic ambiguity. Leuk Res 30: 1227-1233, 2006. 